\title{
Evaluation of bacterial load of frozen chicken thighs in Mosul markets
}

\author{
A.M. Shareef, R.A. Farag and E.K. Al-Ruthwani \\ Department of Veterinary Public Health, College of Veterinary Medicine, University of Mosul, Mosul, Iraq
}

\begin{abstract}
This paper presents an investigation of the microbiological quality of frozen chicken thighs sold in Mosul markets. Bacteriological analysis was performed on 60 samples (30 samples of local origin, and 30 imported ones) of frozen thighs kept in deep-freezers at $-18 \mathrm{C}^{\circ}$. Samples were then tested for total count of aerobic mesophilic bacteria (APC) and Staphylococcus aureus. With regards to microbiological quality and contamination of frozen chicken thighs, APC was found within the acceptable limits of satisfactory products. Staphylococcus aureus were isolated in $16.66 \%$ from imported thighs versus $33.33 \%$ in local ones, with $<10^{2} \mathrm{CFU} / \mathrm{cm}^{2}$ in both thigh types. Antimicrobial sensitivity of $15 \mathrm{~S}$. aureus isolates were surveyed for susceptibilities to a panel of 7 antimicrobial agents. They were $100 \%$ resistant to ampicillin; $33.34 \%$ to erythromycin and tetracycline; $26.67 \%$ to Trimethoprim+sulfamethoxazol; $20 \%$ to Doxycyclin; $13.34 \%$ to Enrofloxacin, and 100\% susceptible to vancomycin. Results of this experiment suggest that both types of frozen chicken thighs were fit for human consumption.
\end{abstract}

Keywords: Frozen chicken; Bacterial count; Antibiotics.

Available online at http://www.vetmedmosul.org/ijvs

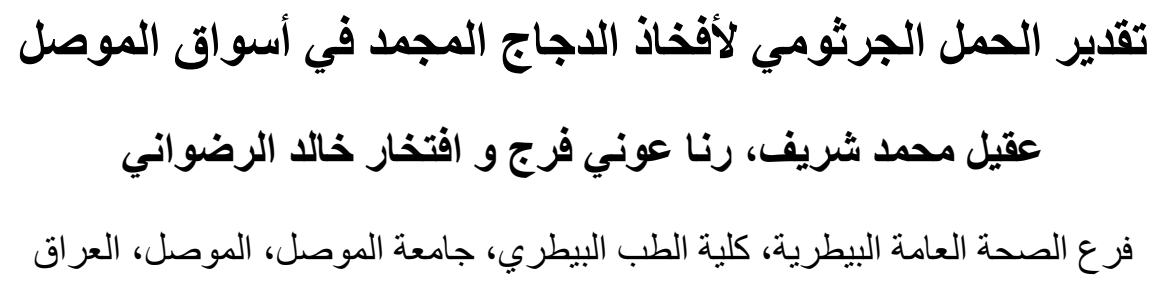

الخلاصة

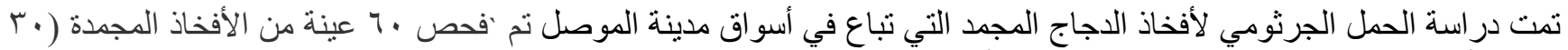

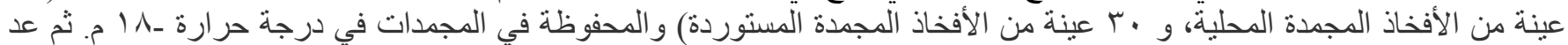

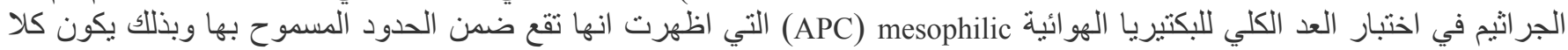

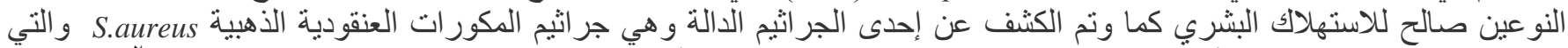

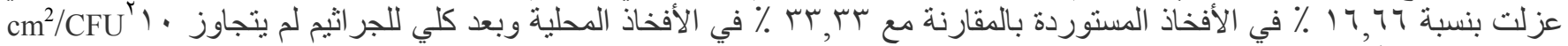

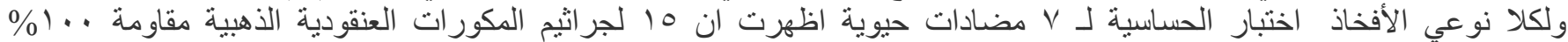

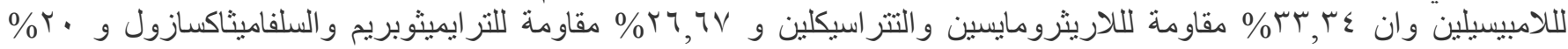

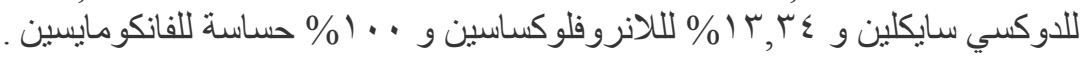

\section{Introduction}

Broiler chicken meat and its products are liable to contamination with various kinds of spoilage microorganisms from different kinds of sources $(1,2)$. Such contamination may render the chicken meat unsafe to consumer or impair its quality. Aerobic plate count is a commonly recommended microbiologically method for estimating the food shelf life Esherichia coli and staphylococcous aureus could be used as indicators for the contamination of broiler pathogens (3).

El-Khateib et al. (1) found that the total bacterial count of chicken products was $10^{6}-10^{7}$ Colony forming unit (CFU) $/ \mathrm{g}$, and Staphylococcus aureus was isolated at incidence of $20 \%-40 \%$. Unfortunately, poultry meat offer ideal medium for microbial growth because they are highly nutritious, have a favourable $\mathrm{pH}$ (4). Ready to eat poultry and poultry products in which the level of $S$. aureus have reached $10^{6} \mathrm{CFU} / \mathrm{g}$ may cause illness, (5). Food safety 
aspects of poultry industry were discussed by (6), in sections which consider: the growing awareness of food safety issues during the last two decades; the importance of food inspection services, risk assessment and management is increasing life expectancy in developed countries. In addition to the potential dangers from food poisoning, as related to the shift in emphasis from carcass inspection to microbiological criteria and the increasing sensitivity of many quality tests; establishment of standards. These affected by political considerations; as the significance of quality of poultry meat products to all involved in their production, handling and consumption; and the role of communication and education in improving the situation (7). Factors contributing to the increase in food poisoning are related to both foods eaten and their preparation. The implication of foods of animal origin as principle vehicles of infection was strengthened by reports associating these foods with outbreaks of human illness, However, poultry products can harbour food-borne pathogens, like Salmonella stereotypes, Campylobacter jejuni, Listeria monocytogens, C. perfringens and S. aureus (8). Poultry and poultry products rank first or second in foods associated with disease in most of the countries all over the world (9) The food poisoning microorganisms causing outbreaks were mainly Salmonellae and $S$. aureus with an incidence of 8.99 and 11.54, respectively, while incidence of other food poisoning microorganisms causing $4.07 \%$ of the cases (10).

The modern poultry industry accomplished through genetic selection, improved feeding, keen health management practices involving usage of antibiotics to treat bacterial disease in intensive farming system (11). The antibiotic selection pressure for resistance in bacteria in poultry is high and consequently their faecal flora contains relatively high proportion of resistant bacteria (12). Resistant strains from the poultry gut readily soil poultry carcass when they are being scarified and as a result poultry meats are often contaminated with multi-resistant bacteria. In light of this, there is probability that most pathogenic bacteria that threaten human health may soon be resistant to all known antibiotics (13).

Little is known about the microbiological aspects, shelf life, keeping quality food safety and antibiotic resistance to pathogenic microorganisms of commercially processed chicken meat in Mosul city, therefore, the present study was designed to evaluate some bacteriological quality parameters of the frozen chickens thigh sold at Mosul city markets with special reference to food poisoning microorganism, S. aureus.

\section{Materials and methods}

At interval from 2010-2011, sixty samples of frozen chicken thighs were purchased from Mosul meat retails (30 local, and 30 imported samples). Local thigh samples were obtained by partitioning local chicken carcass into four parts, one thigh sample was obtained aseptically and subjected to analysis. Each set of samples were shipped frozen to the laboratory in the department of veterinary public health, college of veterinary medicine, for aerobic plate count and for enumeration of $S$. aureus,

\section{Preparation of samples}

Samples were prepared according to (14) with simple modification, in which samples were left-packaged in fridge for thawing at $4 \mathrm{C}^{\mathrm{o}}$ for $18 \mathrm{~h}$. The mass of frozen thighs (300-500 g) was recorded, then transferred with the accompanying fluid from its original packaging material into a plastic bag of suitable size. Hundred $\mathrm{ml}$ of 0.1 percent peptone solution was add. The open end was tied, and by massaging around the sample from the closed end to the open end, half the air from the bag was remove. Shaking vigorously for 2 minutes was practiced. Then we release the rinse fluid into a sample container by aseptically cutting off a corner of the bag with sterilised scissors and allowing the fluid to run into the container. The rinse fluid is the first dilution. One $\mathrm{ml}$ of the rinse fluid was pipetting onto an agar plate, then we carried out a series of dilutions by pipetting $1 \mathrm{ml}$ from the rinse fluid into $9 \mathrm{ml}$ peptone solution dilution blanks $\left(10^{1}-10^{6}\right)$ to establish an optimum counting range of 25-250 colonies on agar.

\section{Dry Aerobic Plate Count (APC) agar}

Using the method described by (15), $1 \mathrm{ml}$ was plated from each dilution onto duplicate APC agar. Samples were dispensed onto plates within 20 minutes of preparing the initial dilution, and incubated at $30 \pm 1 \mathrm{C}^{\circ}$ for $48 \pm 3$ hours. Colonies were counted on the duplicate plates. The countable range is $25-250 \mathrm{CFU}$.

\section{Enumeration of $S$. aureus}

Mannitol salt plates were Pipetted with $1 \mathrm{ml}$ from the $10^{1}-10^{6}$ sample dilutions in duplicate using separate pipettes for each dilution. Inoculums were distributed evenly over the surface of the plates then plates were inverted and incubate at $35 \pm 1 \mathrm{C}$ for $45-48$ hours.

The countable range is $25-250$ colonies on all plates. Biochemical tests for confirmation of S.aureus were carried out according to (16), Ten colonies from suspected bacteria (changed media to yellow) were selected and inoculated into separate tubes containing $0.2 \mathrm{ml}$ of BHI broth for coagulase testing. Rabbit plasma $(0.5 \mathrm{ml})$ with EDTA were added, mixed thoroughly and incubated at $35 \pm 1 \mathrm{C}^{\circ}$ for 18 $24 \mathrm{~h}$. Examination of these tubes were done periodically over $6 \mathrm{~h}$ interval for clot formation. Any degree of clotting was interpreted as a positive reaction. Calculating the total number of colonies represented by coagulase positive cultures and multiply by the appropriate sample dilution 
factor to record the number of coagulase positive staphylococci (17).

Calculation of the total number of colonies in both agars was carried out as follow:

$$
N=\frac{\sum c}{\left[\left(1 \times n_{1}\right)+\left(0.1 \times n_{2}\right) \times(d)\right.}
$$

where: $\mathrm{N}=$ Number of colonies per $\mathrm{ml}$ or $\mathrm{g}$ of product, $\sum \mathrm{C}$ $=$ Sum of all colonies on all plates counted, $\mathrm{n}_{1}=$ Number of plates in first dilution counted, $\mathrm{n}_{2}=$ Number of plates in second dilution counted, $\mathrm{d}=$ Dilution from which the first counts were obtained.

The following formulas used for calculating the surface area of the frozen legs in square centimetres: $60 n+0.90 m$ Where $m=$ Mass of thigh piece in grams, $n=$ number of thigh pieces.

The following formula used for calculating the colony forming units $(\mathrm{CFU}) / \mathrm{cm}^{2}$ :

Colony forming units $(\mathrm{CFU}) / \mathrm{cm}^{2}=$ Number of colonies X volume of rinse fluid (100ml) $\mathrm{X}$ dilution

Surface area of poultry meat

\section{Antimicrobial susceptibility testing Disk diffusion method}

Fifteen S. aureus isolates were subjected for antimicrobial sensitivity to a panel of 7 antimicrobial agents Antimicrobial resistance tests were performed by the agar disk diffusion method (18). Suspension of (15 minutes $S$. aureus colonies incubation) was used. The broth was swabbed evenly onto the surface of Muller-Hinton agar, a paper disks impregnated with antimicrobial agents were applied to the surface of the agar using sterile cotton swabs, and the covered plates were allowed to dry. Antibioticimpregnated filter paper disks were placed on the surface of the agar and incubated at $37^{\circ} \mathrm{C}$ for $24 \mathrm{~h}$. Four disks were placed on the agar surface for each isolate, for a total of 7 disks (1 for each antibiotic tested). Discs with the following concentration of antibacterial substances ( $\mu \mathrm{g} / \mathrm{disc})$ were used as follows: Ampicillin (Amp)-10; Erythromycin(Ery)15; Enrofloxacin (Enr)-5; Vancomycin (Van)-30; Tetracyclin (Tetra)-30; rimethoprim + sulfamethoxazol (TS)-25; Doxycyclin (Dox)-30 measuring the diameter of the zones of inhibition and for interpretation the three-stage system of Brown was used (19).

\section{Multiple antibiotics resistance indexing of isolates}

The Multiple Antibiotic Resistance (MAR) index is defined as $a / b$ where ' $a$ ' represents the number of antibiotics to which the particular isolate is resistant and ' $b$ ' the number of antibiotics to which the isolate is exposed (20).

\section{Results}

The results of the bacteriological examination of local and imported frozen chicken thigh samples are presented in table 1 to 3 and figure 1,2 and 3. The data on the APC of both types of samples are tabulated in table 1 . The total bacterial count for local chicken thigh samples were $4.75 \pm 0.35 \log 10 \mathrm{CFU} / \mathrm{cm}^{2}$, which is higher significantly than the bacterial count of the imported samples in which they were $3.81 \pm 0.25 \log 10 \mathrm{CFU} / \mathrm{cm}^{2}$. The interval $\mathrm{Log}$ $\mathrm{CFU} / \mathrm{cm}^{2}$ was 4-5 in local samples and 3-4 in imported ones with a difference in a mean value in $\log 10 \mathrm{CFU} / \mathrm{cm}^{2}$ of 0.94. Staphylococcus aureus count was $1.61 \pm 0.16 \log 10$ $\mathrm{CFU} / \mathrm{cm}^{2}$ in local samples with a higher significant differences $(\mathrm{P}<0.05)$ than those of imported samples $\left(0.63 \pm 0.05 \log 10 \mathrm{CFU} / \mathrm{cm}^{2}\right)$. The interval $\mathrm{Log} \mathrm{CFU} / \mathrm{cm}^{2}$ was 1-2 in local samples and $<1$ in imported ones with a difference in a mean value in $\log 10 \mathrm{CFU} / \mathrm{cm}^{2}$ of 0.98 . The percentage of $S$. aureus from all imported thigh samples were $16.66 \%$ compared to about two folds ( $33.33 \%$ ) higher in local samples Fig. 1). The majority of the 15 S.aureus isolates from local and imported thighs, showed antibiotic resistance to one or more antibiotics. The overall percentage of antibiotic resistance in Figure 2, show that $100 \%$ of the isolates were resistant to ampicillin; $33.34 \%$ were resistant to both erythromycin and tetracycline; $26,67 \%$ were resistance to Trimethoprim+sulfamethoxazol; $20 \%$ were resistance to Doxycyclin and $13.34 \%$ were resistance to Enrofloxacin, while all the isolates were susceptible to vancomycin. Multidrug resistance of $S$. aureus isolates from samples (Table 4), clears that 2 strains $(40 \%)$ of S.aureus isolated from imported thighs were resistant to one antibiotic, while the other 3 strains $(60 \%)$, of the organism were resistant to 2 antibiotics. The resistance in S.aureus strains of the local thigh samples show worse situation when compared with the imported samples, since 1 strain (10\%) was resistant to 4 antibiotics; 5 strains $(50 \%)$ to 3 antibiotics; 3 strains $(30 \%)$ to 2 antibiotics and 1 strain $(10 \%)$ was resistant to 1 antibiotic. Combining the multiple resistance of both strains isolated from local and imported thigh samples (Figure 3), it is evident that $20 \%$ of the strains were resistant to 1 antibiotic; $40 \%$ to 2 antibiotics; $33.33 \%$ to 3 antibiotics, while $6.66 \%$ of the strains were resistant to 4 antibiotics. The multiple resistance index of S.aureus strains from imported thigh samples were 0.227 , while that of the local samples were 0.356 . 
Table 1: Mean counts of the APC, S. aureus counts $\left(\log / \mathrm{cm}^{2}\right)$ in local and imported frozen chicken thigh samples.

\begin{tabular}{lccc}
\hline Sample origin & $\begin{array}{c}\text { Samples } \\
\text { No. }\end{array}$ & APC & $\begin{array}{c}\text { S.aureus } \\
\text { count }\end{array}$ \\
\hline $\begin{array}{l}\text { Local frozen } \\
\text { chicken thigh } \\
\text { samples }\end{array}$ & 30 & $4.75 \pm 0.35^{*}$ & $1.61 \pm 0.16^{*}$ \\
$\begin{array}{l}\text { Imported frozen } \\
\text { chicken thigh } \\
\text { samples }\end{array}$ & 30 & $3.81 \pm 0.25$ & $0.63 \pm 0.05$ \\
$\begin{array}{l}\text { Mean absolute value } \\
\text { of differences in } \\
\text { counts }\left(\mathrm{CFU} / \mathrm{cm}^{2}\right)\end{array}$ & & 0.94 & 0.98 \\
$\begin{array}{l}* \text { Mean counts with the different letters are significantly } \\
\text { different }(\mathrm{P} \leq 0.05) .\end{array}$
\end{tabular}

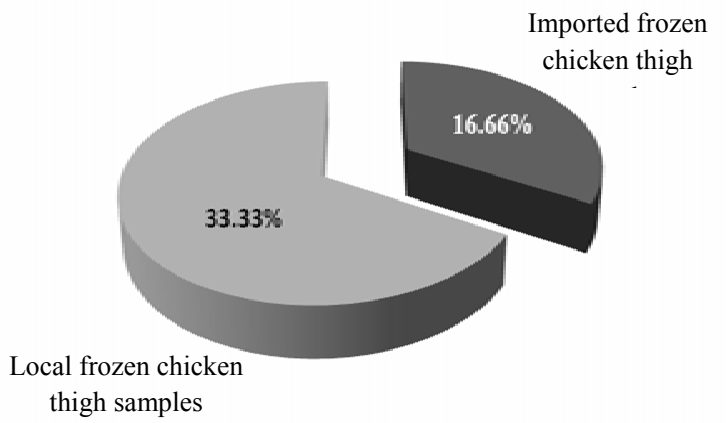

Figure 1: Prevalence of countable S. aureus in imported and locally processed frozen chicken thigh sample.

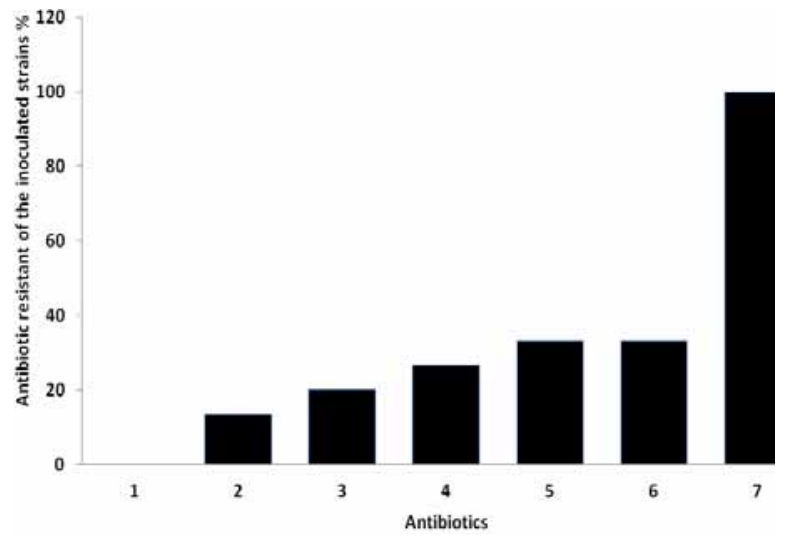

Figure 2: Overall percentage of Antibiotic resistant profile for the isolated S.aureus from frozen chicken thigh samples $1-$ Van = Vancomycin; 2- Enr $=$ Enrofloxacin; 3- Doc $=$ Doxycyclin; 4- TS = Trimethoprim+sulfamethoxazol; 5Tetra $=$ tetracycline; 6- Ery $=$ erythromycin; 7- Amp = ampicillin.

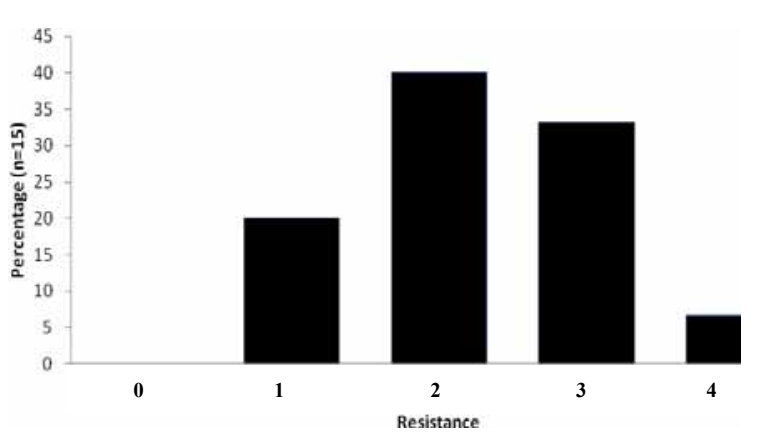

Figure 3: Overall multiple antibiotic resistance phenotypes of $S$. aureus isolates of frozen chicken thigh samples.

Table 2: Frequency distribution results in the examined frozen chicken thigh samples.

\begin{tabular}{|c|c|c|c|c|c|c|c|c|c|}
\hline \multirow{3}{*}{$\begin{array}{l}\text { Interval } \\
\text { Log CFU/cm2 }\end{array}$} & \multicolumn{4}{|c|}{ APC } & \multirow{3}{*}{$\begin{array}{c}\text { Interval } \\
\text { Log } \\
\text { CFU/cm2 }\end{array}$} & \multicolumn{4}{|c|}{ S.aureus count } \\
\hline & \multicolumn{2}{|c|}{ Local } & \multicolumn{2}{|c|}{ Imported } & & \multicolumn{2}{|c|}{ Local } & \multicolumn{2}{|c|}{ Imported } \\
\hline & $\mathrm{F}$ & $\%$ & $\mathrm{~F}$ & $\%$ & & $\mathrm{~F}$ & $\%$ & $\mathrm{~F}$ & $\%$ \\
\hline$<3$ & 0 & 0 & 0 & 0 & $<1$ & 0 & 0 & 5 & 100 \\
\hline $3-4$ & 0 & 0 & 30 & 100 & $1-2$ & 10 & 100 & 0 & 0 \\
\hline $4-5$ & 30 & 100 & 0 & 0 & $2-3$ & 0 & 0 & 0 & 0 \\
\hline$>5$ & 0 & 0 & 0 & 0 & $>3$ & 0 & 0 & 0 & 0 \\
\hline
\end{tabular}


Table 3: Multidrug resistance of S. aureus isolates from Frozen chicken thigh samples.

\begin{tabular}{ccccccc}
\hline Multiple drug & \multicolumn{5}{c}{ Frozen broiler thigh samples } \\
\cline { 2 - 7 } $\begin{array}{l}\text { resistant } \\
\text { isolates }\end{array}$ & No. $\%$ & MAR & No. & $\%$ & MAR \\
\hline 1 & 2 & 40 & & 1 & 10 & \\
2 & 3 & 60 & 0.227 & 3 & 30 & 0.356 \\
3 & 0 & 0 & & 5 & 50 & \\
4 & 0 & 0 & & 1 & 10 & \\
\hline
\end{tabular}

\section{Discussion}

Heavy loads of bacteria enter the processing plant with the life birds, and these bacteria can be disseminated throughout the plant during processing. Chickens thigh is of main importance in investigating the contamination during poultry slaughtering process, which is referred by (21), who showed that the highest bacterial count were seen in meat tissues of thigh among all parts of chicken carcass. In the present study, APC recovery for local frozen chickens thigh samples were $4.75 \log 10 \mathrm{CFU} / \mathrm{cm}^{2}$, a significant one logarithmic cycle over the imported ones $3.81 \log 10$ $\mathrm{CFU} / \mathrm{cm}^{2}$. Both counts were occur within the microbiological specification of standard set for frozen chickens of $10^{5}$ to $10^{6}$, and within the maximum acceptable microbiological limits (22), that APC of frozen chicken when it occurs $<106$, the product is satisfactory and could be used for human consumption, but when level ranged between $10^{6}-<10^{8}$, the product is accepted as moderately satisfactory for human consumption, and only when APC exceeds $10^{8}$, the product is considered as unfit or unsatisfactory for human consumption (23). Our results of APC were more than those recovered by (20) on frozen chicken thigh, who found that APC were of $\log 101.81$ to $2.69 \mathrm{CFU} / \mathrm{g}$ after 10,20 and 30 days storage at $-18 \mathrm{C}$. Although we have no idea about the time elapsed between slaughtering and purchasing our samples, but this may be due to bacterial reduction during storage, based on the findings of the mentioned authors, when they declared the effect of freezing storage on the reduction of APC in fresh thigh samples changed from $\log 105.74-6.65 \mathrm{CFU} / \mathrm{g}$ to $\log 101.81-2.69 \mathrm{CFU} / \mathrm{g}$ after 10,20 and 30 days storage at $-18 \mathrm{C}$; or from 3.5 to $5.5 \log 10 \mathrm{CFU} / \mathrm{cm}^{2}$ (23), and from $10^{4}$ to $10^{5} \mathrm{CFU} / \mathrm{cm}^{2}$ (24) from the initial total viable count. The mean absolute value of difference $(\log 10 \mathrm{CFU} / \mathrm{cm} 2)$ between local and imported samples here was equal to one logarithmic cycle. The higher counts in local samples were suggests poor quality issue and possible poor temperature control. Undoubtedly the poultry slaughtered and dressed under local conditions in Mosul city, may carry high initial contamination bacterial load from the point of slaughtering process to the point of offering to consumers. There occurs biomagnifications at all levels of handling, poor transport and retailing conditions. In the other side, the improved hygienic measures applied in the abroad slaughter houses through application of hazard analysis of critical control points programms and the fulfilment of the European ISO certificates in the imported samples, will reduce the initial contamination, in addition to the proper sanitary applications to the distribution and retailing conditions and the inherent cold chain through to the consumers could in fact meet the challenge to deliver a safe good quality product. Although APC in local and imported chicken thigh is in general regarded as an indicator of quality assessment of long self foods like poultry, but it is not indicator of safety. In our study, APC in local and imported frozen thigh samples indicate that they were in acceptable limits, but the contamination with $S$. aureus at a rate of $16.66 \%$ in imported samples and $33.33 \%$ in local samples, with significant $(\mathrm{P}<0.05)$ higher $S$. aureus APC in local samples, $\left.\log 101.61 \mathrm{CFU} / \mathrm{cm}^{2}\right)$ versus $\left(\log 100.63 \mathrm{CFU} / \mathrm{cm}^{2}\right)$ in imported samples. These results give an important indication about the safety and hygienic quality of chicken thighs, since these microorganisms are one of the aetiological causes in food poisoning (25). Our results of Staphyloccus areus isolation and enumeration in both samples were not complying with and were higher than that reported by (20), who isolate the organism at a rate of 90.63 $\%$, with a range of $\log 102.69-3.66 \mathrm{CFU} / \mathrm{cm}^{2}$ in fresh chicken carcass and in a range between log 101.23 to 2.69 $\mathrm{CFU} / \mathrm{cm}^{2}$ after storage in freezing condition up to 30 days. Our results in the other hand, were coincide with ALDughaym et al., (26), who found that S.aureus were found to be $<10^{2} \log 10 \mathrm{CFU} / \mathrm{cm}^{2}$, in frozen chickens in Saudi Arabia. The pre and post slaughtering sources of S.aureus are many, of these feed, faeces, feather, air scald water and defeathering machine (in the cracks of the rubber fingers) and employees $(27,28)$. So, poultry serve as a reservoirs for a number of pathogens including S.aureus that capable of enterotoxine production (29). These organisms are generally low in the first few weeks of chicks life, but then they tend to increase as chick grows older and tend to be relatively high at the age of slaughtering, i.e., 5-7 weeks of life. The bacterium is considered to be a normal resident of the chickens, located on the skin and feathers and in the respiratory and intestinal tracts (30). During the process of slaughtering, contamination with $S$. aureus could gain from high poultry concentration, slaughtering and processing equipments and calling devices, in addition to the processes of scalding and evisceration, due to cross-contamination, are responsible for increased S.aureus contamination (31). The organism is also found to be one of the other genera of microorganisms in the slaughtering processing wastes (32). The average S.aureu percentage in our study were in the order of (33), who found that this microorganism was one of the microorganisms in different frozen chicken batches with a percentage of $21.33 \%$, HPA quid lines (23), 
concluded when the number of S.aureus $>10^{4}$ in poultry products is considered to be at high risk potential and injurious to human health or not fit for human consumption which give a strong evidence for poor handling and temperature control, and when the number range between $<10^{4}-10^{2}$, the product is said to be at moderate risk to human health and so give an evidence of poor handling and temperature control. The reduction of S.aureus to numbers $>10^{2}$, is recommended to be safe for human consumption. The results found here showed that S.aureus was found in $>10^{2} \mathrm{CFU} / \mathrm{cm}^{2}$ in both local and imported thigh samples. These microorganisms were higher in about one logarithmic cycle in local samples than those of imported ones. This difference may be due to the higher S.aureus contamination during handling and packing of local chicken thighs. Or to the variation in the temperatures during distribution of deep frozen chicken thighs. In practice, the main problem is the use in retail stores of open frozenfood-display cabinets with automatic defrosting devices. As a consequence of 2 to 4 or more defrosting cycle per day (Especially here in Mosul city), the temperature of the product can rise periodically to slightly below zero, zero or even higher, depending upon the display mode of packages (34). In the current study, we characterized the resistance prophile among S.aureus strains isolated from imported and local chicken thighs. We further demonstrated the prevalence of multidrug resistance, including resistance to clinically important antibiotics such as, enrofloxacin; doxycyclin; trimethoprim+ sulfamethoxazol; tetracycline; erythromycin and ampicillin. Of these, tetracyclines (Oxytetracycline and chlorotetracycline) are used as growth -promoting antibiotics. Fortunately, all strains were susceptible to vangomycin, the drug commonly used to methecillin resistant S. aureus (MRSA) (35). The 100\% resistance to ampicillin and susceptible to varying degrees to other antibiotics like enrofluxacin, trimethoprim + sulfamethoxazole, tetracycline and vancomycin was also reported earlier (36). S.aureus contaminated local samples had a notable higher multidrug resistance (4 antibiotics) and resistance index of $>0.2(0.356)$, compared to absence of multidrug resistance in imported thigh samples with index of $>0.2$. Multi antibiotic resistance index values higher than 0.2 are considered to have originated from high-risk sources where antibiotics are often used (20). This finding may be explained by that in conventional local poultry feeding operation, antibiotics are routinely administered in feed and water for extended period, providing the necessary foundation for the emergence and proliferation of multidrug resistance (37) In poultry, antibiotics may be administered to whole flocks rather than individual animals, and antibiotics may be continuously fed to broilers, layers and turkey. But randomly, inappropriate, non-specific, misuse or abuse of antibiotics as growth promoters and/or for therapeutic purposes (as here in Mosul city also) are considered to be the major contributor to the emergence of antibiotic -resistant bacteria and consequently their faecal flora contains a relatively high proportion of resistant bacteria $(38,39)$. In other countries, drugs that have been registered for therapeutic use in humans or animals, or both, are not allowed to be used as growth promoters (37). So, the major factors selecting for antimicrobial resistance in bacteria is antibiotic use, crowding and poor sanitation, these three factors are typical of intensive poultry farming and explain the degree of resistance (40). From the above results, a bacteriological survey of frozen poultry and poultry products should be undertaken with a series of random samples taken directly from the majority of the producers and not from retail freezer cabinets.

\section{Acknowledgments}

The authors are grateful for the financial support from the College of Veterinary Medicine, University of Mosul.

\section{References}

1. Mountney GJ. Poultry products technology. AVI, Westport, Connecticut. PHLS : Guidelines for the microbiological quality of some ready to eat foods sampled at the point of sale. Comm.Dis. and Public Health. 2000; 3(3): 163-167.

2. Mehlman IJ, Romero A. Enteropathogenic Escherichia coli methods for recovery from foods. Food Tech., $1982 ; 36(3): 73$.

3. International Commission on Microbiological Specifications for Foods (ICMSF). Microorganisms in Foods 2. Sampling for microbiological analysis: Principles and Specific Applications. 2nd ed., International Commission on Microbiological Specifications for Foods. Blackwell Scientific Publications, Oxford. 1986.

4. Johnston RW, Tompkin RB. Meat and poultry products. In: Compendium of Methods for the Microbiological Examination of Foods. American Public Health Assoc. "APHA", 1992: pp. 821-835.

5. Tompkin RB. Indicator organisms in meat and poultry products. Food Technol. 1983; 37 (6): 107-110.

6. Hunton P. Food safety: everybody's business. Misset World Poult. 1997; 13 (7): 13-15.

7. Altabari G. Meat Hygiene and Safety. AL-Ahsa Municipality, 2009: p. 311.

8. Waldroup AL. Contamination of raw poultry with pathogen. World's Poult Sci. 1996; 52: 7-25.

9. Bean NN, Griffin PM. Food borne disease outbreaks in the United States, 1973-1987; pathogens, vehicles and trends. J. Food Prot. 1990; 53: 804-817.

10. Altabari G, Al-Dughaym AM. The role of sanitary inspection of meat in relation of food poisoning. In: The Second Annual Scientific Meeting for Environment Hygiene (Meat Hygiene), Riyadh, 2002: pp. 180-203.

11. Apata DF. Antibiotic resistance in poultry. Int $\mathrm{j}$ poult sci.,2009; 8: 404-408.

12. Van der bogaard AE, London N, Driessen C, Stobberingh EE Antibiotic resistance of faecal Escherichia coli in poultry. poultry farmers and poultry slaughteres. J Antimicrob Chemother. 2001; 47: 589-607.

13. Mathur S, Singh R. Antibiotic resistance in food lactic acid bacteriaAreview. Int J Food Microbiol. 2005; 105: 281-295.

14. Australian standard for construction of premises and hygienic production of poultry meat for human consumption (AS). Appendix 
A. microbiological testing for process monitoring in the poultry meat industry guidelines 4465: 2001 (appendix a guidelines) 13 pages.

15. USDA:United States Food Safety Office of Laboratory QA/QC Division Department of Public Health 950 College Station Road Agriculture Service Science Athens, GA 30605 Laboratory Guidebook Quantitative Analysis of Bacteria in Foods as Sanitary Indicators, 2001.

16. Bennett RW, Yeterian M, Smith W, Coles CM, Sassaman M, McClure FD Staphylococcus aureus identification characteristics and enterotoxigenicity. J. Food Sci. 1986; 51:1337-1339

17. Sperber WH, Tatini SR. Interpretation of the tube coagulase test for identification of Staphylococcus aureus. Appl. Microbiol. 1975; 29:502-505.

18. Prescot H. Laboratory exercises in microbiology. $5^{\text {th }}$ ed.The McGrawHill C ompanies.2002: $466 \mathrm{p}$.

19. Brown AE. Bensons microbiological application. Laboratory manual in general microbiology. Complete version. 9th ed. McCraw-Hill Companies, Inc.2005: $510 \mathrm{p}$.

20. Krumperman PH. Multiple antibiotic resistance indexing of Escherichia coli To indentify high-risk sources of faecal contamination of foods. Applied.Environ.Microbiol.1983;46:165-170.

21. Rahman MM, Rahman MM. Microbial contamination of meat and their public health significance. Bangladish Vet J.,1998;13:1-6.

22. Gracey JF, Collins DS, Huey RJ. Meat hygiene. $3^{\text {rd }}$ edition. W.B. Saunders companyLTD. London, 1999

23. Health Protection Agency (HPA) draft quid lines for assessing the microbiological safety of ready to eat foods. Consultation from $1 / 12 / 2008-20 / 2 / 2009$.

24. Mahizea. Investigations on the influence of pre slaughter stress on the endogenic microbial contamination in broiler carcass. Berliner and Munclener Tierarztliche Wochensclrift,1994;109:24-31.

25. Barness DG, Watts AB. A note on a method of sampling chicken carcasses for total carcass composition proximate analyses. Poultry Science, 1976;55:2474-2476

26. Jay, J.M., Loessner, M.J., Golden, D.A., Fresh Meats and Poultry, in modern food microbiology. Springer, New York, 2005 :59-85..

27. AL-Dughaym AM, Altabari GF. Safety and quality of some chicken meat products in AL-Ahsa markets -Saudi Arabia. Saudia J Biol Sci.,2010;17:37-42.
28. Soliman SE, Reddy PG, Mohammad SAA, Busby H, Rowe ES. Epidemiological surveillance on environmental contaminantsin poultry farms. Int j poult sci., 2009; 8: 151-155.

29. Adegunloye DV. Microorganisms associated with poultry faeces. J Food Agricul Environm.,2006; 4: 41-42.

30. Bennett RW. Atypical toxigenic Staphylococcus and nonstaphylococcus aureus species on the Horizon? An update.J Food Protection.1996; 59: 1123-1126.

31. Shareef AM, Mansour RS, Ibrahim KK. Staphylococcus aureus in commercial breeder layer flocks. Iraqi J Vet Med. 2009; 23: 63-68.

32. Lidija K, Mirza H, Nevijo Z., Microbiological quality of poultry meat on the Croatian markets.Vet Arhiv, 2006; 76: 305-313.

33. Gong JR, ForesterJ YU H, Chambers JR, Sabour PM, Wheatcroft R, Chen S. Diversity and phylogenetic analysis of bacteria in yhe mucosa of chicken ceca and comparison with bacteria in the cecal lumen. FEMS Microbiol Lett. 2002; 208: 1-6

34. Bal C. Effect of storage conditions on poultry meat from sales units. Analele Universita Nii din Oradea Ffascicula: Ecotoxicologie., Zootehnie si Tehnologii de Industrie Alimentarara,2010.

35. Lorentzen G. Food preservation by refrigeration a general introduction. Int J Refrig., 1978; 1: 13-26.

36. Andrew EW, Tania CC, Jordan B, Cindy ML, Lindsey W, Kimberly P, Jeffrey TF, Jolene B, Elizabeth MD, David ME, Paul SK, Lance P. Multidrug -resistant Staphylococcus aureus in US meat and poultry. Clin infect Dis, 2011;dio:10.1093/cid/cir181.

37. Kawano J,Shimaizu A, Saitoh Y, Yagi M, Saito T, Okamoto R. Isolation of methicillin -resistant coagulase-negative staphylococci from chickens.J Clin Micrbiol, 1996; 34: 2072-2077

38. Bogaard AE, Stobberingh EE. Antibiotic usage in animals: impact on bacterial resistance and public health. Drug 1999; 58: 589-607.

39. Khachatourians GG.Agricultural use of antibiotics and the evolution and transfer of antibiotic -resistant bacteria. JAMC. 1998; 159: 11281136.

40. Van den bogarrd AE. Antimicrobial resistance -relation to human and animal exposure to antibiotics. J Antimicobial Chemotherapy,1997; 40: 453-454. 